Ministrv of Economv and Finance

Department of the Treasurv

Analisi e Programmazione

Economico Finanziaria

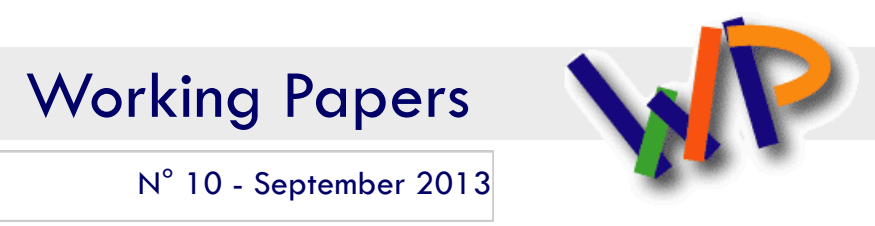

ISSN 1972-411X

\title{
Reforms, labour market functioning and productivity dynamics: a sectoral analysis for Italy
}

Cecilia Jona Lasinio, Giovanna Vallanti

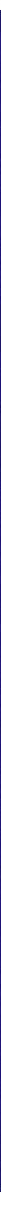




\section{Working Papers}

The working paper series promotes the dissemination of economic research produced in the Department of the Treasury (DT) of the Italian Ministry of Economy and Finance (MEF) or presented by external economists on the occasion of seminars organized by MEF on topics of institutional interest to the DT, with the aim of stimulating comments and suggestions.

The views expressed in the working papers are those of the authors and do not necessarily reflect those of the MEF and the DT.

\section{(C) Copyright:}

2013, Cecilia Jona Lasinio, Giovanna Vallanti.

The document can be downloaded from the Website www.dt.tesoro.it and freely used, providing that its source and author(s) are quoted. 


\section{CONTENTS}

1 INTRODUCTION

2 THEORETICAL BACKGROUND AND EMPIRICAL EVIDENCE …………………………..... 3

3 LABOUR MARKET FACTS AND LABOUR PRODUCTIVITY TRENDS ……….................... 7

3.1 Labour market reforms ………………………………………………………………………

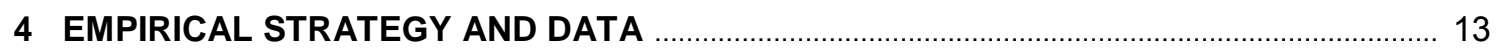

4.1 Labour market reforms and industry productivity ............................................................. 14

4.2 Labour market institutions and the reallocation component ………………………........... 16

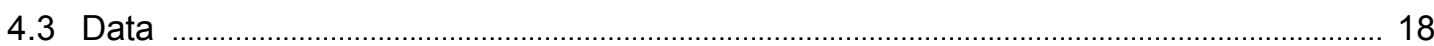

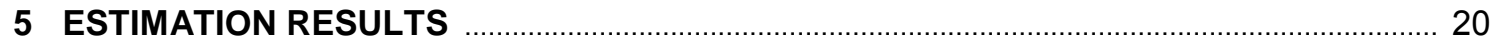

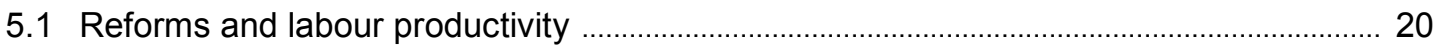

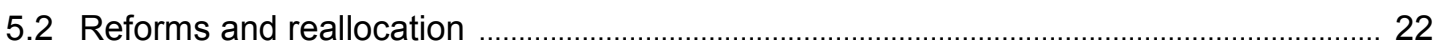

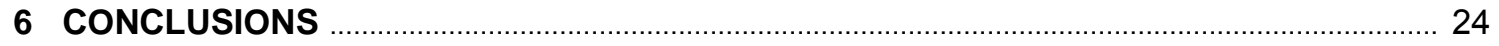

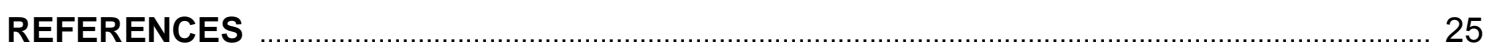

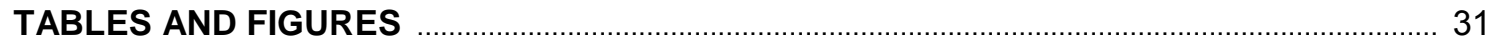





\title{
Reforms, labour market functioning and productivity dynamics: a sectoral analysis for Italy
}

\author{
Cecilia Jona Lasinio*, Giovanna Vallanti**
}

\begin{abstract}
Over the last two decades Italy registered notable improvements in the performance of the labour market both in terms of unemployment and participation. However, such improvements have been accompanied by a deterioration of productivity and competitiveness. This paper provides evidence in this respect evaluating to what extent labour market reforms might have influenced the poor productivity performance of the Italian economy over the period 1980-2008. Our results show that the increased flexibility in the use of temporary contracts has led to a lower productivity (level and to a lesser extent growth rate) in all sectors, with a higher impact on those sectors with a larger technological need for flexibility and a lower skill content. Moreover, the reforms had a negative impact on the productivity-enhancing reallocation by favoring a shift of employment towards low-productive industries. The negative effect of the reforms on the reallocative capacity is stronger in those industries with a higher flexibility need that are also the relatively lower productivity sectors in the period 1993-2008.
\end{abstract}

JEL Classification: J08, J23, J24.

Keywords: Productivity, Fixed Term contracts, Labour Market Institutions.

* Istat and Luiss Lab.

** Luiss University, Luiss Lab and CeLEG. 


\section{Introduction}

In the last two decades the Italian labour market registered notable improvements in terms of employment and job creation. Such results have been attributed to several reforms which were adopted in the eighties and nineties to modify labour market institutions towards a higher degree of flexibility. The Italian labour market has been for decades one of the world's most regulated, with quite stringent legislation on firings. However, over the past two decades, Italy's labour market has undergone important reforms. Some flexibility-oriented reforms took place in the early eighties, with the introduction of temporary apprenticeship contracts (1984) and norms aimed to ease limitations to real wage flexibility (1986). Since the early 90s a number of more substantial reforms have been introduced which have led to some important changes in the regulation of labour market by reducing employment protection levels by facilitating the use of temporary forms of employment and enhancing wage flexibility. Such improvements towards a higher degree of flexibility, however, have been accompanied by a deterioration in terms of productivity and competitiveness (Codogno, 2009; Lucidi, 2008). Italian labour productivity growth started diverging from the trend of other industrialized countries at the end of the 1990s, a phenomenon that does not appear to be cyclical, but a sign of a structural deterioration of Italian competitiveness (Ciriaci and Palma, 2008; Ferrari et al., 2007; Faini and Sapir, 2005). While the impact of labour market reforms on labour utilisation and aggregate unemployment rate has been documented in a number of works, the effects of such reforms on productivity (both in levels and growth) is still an open issue. As the impact of a deregulation in both wage setting and on labour productivity is, in principle, ambiguous, and the empirical evidence is quite inconclusive, structural labour reforms are typically supported on the grounds of promoting an efficient use of labour resources (OECD, 2006).

Our aim is to provide evidence in this respect evaluating from a industry perspective to what extent labour market reforms aimed to deregulate the use of temporary contracts might have influenced the poor productivity performance 
of the Italian economy over the period 1980-2008. A number of works (OECD, 2007; Daveri and Jona-Lasinio, 2005) stressed that if the purpose of the analysis is to investigate the effects of labour market reforms on productivity and competitiveness dynamics, the industry dimension must be considered. In fact, while labour reforms are defined at an aggregate level, their impact is likely to differ across industries. The sector level analysis allows to identify the effects of labour market reforms based on the assumption that reforms impact sectors differently according to their technological characteristics i.e. the industry intrinsic need for reallocation (Cingano et al., 2010). Moreover we exploit the industry dimension of our database, to assess the impact of reforms on the aggregate productivity by looking at the change in productivity within sectors as well as by assessing the role of structural shifts across sectors.

The paper is organized as follows. In the next session we discuss the theoretical motivations and previous empirical evidence. In session 3 we report some stylized facts. In session 4 we discuss the empirical strategy and session 5 reports the results, Session 6 concludes.

\section{Theoretical background and empirical evidence}

From a theoretical point of view, the impact of labour market reforms on productivity (both in levels and growth) is an open issue. Several authors argued that labour market reforms aimed to increase labour utilization may, at the same time, reduce productivity growth (Boeri and Garibaldi, 2007; Dew-Becker and Robert J Gordon, 2008) due to the entrance in the market of the marginal workers (e.g. low skilled workers) and the creation of low productivity jobs (thereby reducing the average quality of the labour supply), or simply because of the presence of diminishing return to labour for a given capital stock (the so called composition effect in Bassanini and Venn, 2008; Nickel and Bell, 1996). The presence of composition effects does not necessarily mean that the productivity of incumbents (jobs and workers) cannot benefit from a more flexibility in the labour market. In fact, any slowdown in average labour productivity 
resulting from a change in employment is, by far, a statistical artefact and does not imply that individual productivity has fallen (OECD, 2007).

Labour market regulation can directly affect workers productivity through several channels: it may (1) influence the incentives for workers and firms to invest in training or education and then affect the composition of human capital; (2) improve the quality of job matching and increase the efficiency of labour resource allocation; (3) encourage the movement of resources between declining or emerging firms/industries/activities by helping firms respond quickly to changes in demand or technology; (4) reduce social conflict by influencing workers' willingness to align their behaviours with their employers' targets; and (5) make labour more expensive and then influence the direction of technological change. This implies that it is, in general, difficult to establish whether the regulation affect the level of productivity, its growth, or both, and in which direction.

In general, labour market regulation affect the capacity of the economy to allocate resources efficiently by imposing limitations to the adjustment of both quantities (employment adjustments) and wages.

Regarding the allocative effects, a key role is played by the employment protection legislation (EPL) whose effect on labour market productivity is ambiguous from a theoretical point of view. On the one hand, stringent EPL is an obstacle to the reallocation of workers and jobs across firms and sectors (Hopenhayan and Rogersons, 1993; Poschke, 2007), reduce the propensity to undertake risky activities (Bartelsman and Hinloopen, 2005), reduce workers' effort (Ichino and Riphahn, 2005) with a negative impact on overall productivity. On the other hand strict protection for regular workers may promote specific investment by firms and workers and result in more learning by doing with a positive effect on productivity (Belot et al., 2007). Moreover partial EPL reform via the introduction/liberalization of temporary forms of employment has an ambiguous effect on productivity depending on the reasons why firms employ temporary workers rather than permanent workers. In principal the use of temporary workers as buffer stocks increases job instability and uncertainty inside the firm, reduces investment in training, lowers workplace cooperation 
and workers' motivations and harms long-run growth prospects (Blanchard and Landier, 2002). Morover the availability of temporary contracts may have a positive effect on job creation (due to a reduction in the expected labour costs) and a negative (temporary) effect on the average labor productivity as a consequence of decreasing marginal returns on labour (Boeri and Garibaldi, 2007). ${ }^{1}$ On the contrary, temporary contracts used as screening devices generate better growth prospects due to better learning about the quality of the match and lower incentive to shirking for temporary workers. This may translate into better job matches and, therefore, more stable and productive employer-employee relationships in the long run (Portugal and Varejao, 2009).

The empirical evidence on the effect of EPL on productivity is quite inconclusive. In fact, depending on the cross-country/industry approach used and the sample of countries considered in the analysis, results suggest both positive and negative effects. Nickell and Layard (1999) reckoned that 'there seems to be no evidence that either stricter labour standards or employment protection lowers productivity growth rates. If anything, employment protection lowers productivity growth if it is associated with other measures taken by firms to enhance the substantive participation of the workforce'.

In order to overcome the identification problem arising from cross-countries regressions on aggregate outcomes, many authors exploit both variation in the regulation across countries/time and the differences in the impact of the regulation in different sectors. Using firm data for a panel of 14 European countries, Cingano et al. (2010) find that EPL reduces labour productivity in high reallocative sectors relative to low reallocative sectors. Their result, however, is not robust to the exclusion of the UK in the sample. Scarpetta and Tressel (2004) analyse the effects of employment protection law and centralized bargaining on firm productivity and dynamics using harmonized data for 17 manufacturing

\footnotetext{
${ }^{1}$ Winfried and Prat (2007) show that EPL has quite different effects across worker and firm types. Their results suggest that less skilled individuals are more affected by strict EPL in terms of a lower quantity of employment. Similarly, EPL seems to drive small or less efficient firms out of the market.
} 
industries in 18 OECD countries, and conclude that strict employment protection law has a significant negative impact on productivity only in countries with an intermediate degree of centralisation / coordination in wage bargaining. Bassanini et al. (2009) examined the dynamic impact of EPL on productivity growth using annual cross-country aggregate data on the degree of regulations and industry-level data on productivity from 1982 to 2003 on 11 OECD countries. They find that dismissal regulation have significant negative impact on total factor productivity. Autor et al (2007) focus on the US case and, by exploiting firm level data, find that an increase in employment protection reduces TFP. A similar result is provided by Cingano et al. (2008) for Italy.

Regarding the effects of temporary contracts on productivity, a number of authors attributed the rather poor labour productivity performance of two tier countries in the last decade, to compositional factors, such as inflows into employment of low skilled workers (Daveri, 2004). With regard to the Italian case, there are a number of recent empirical works which try to assess the effects of temporary contracts on productivity using information at a firm level. Using a panel of Italian firms, Boeri and Garibaldi (2007) find evidence of a negative correlation between temporary employment and productivity implied by their model. Differently, Addessi (2012) suggests that the negative effect of temporary employment on productivity dynamics may be persistent since it affects not only workers' productivity but also their contribution to firm productivity growth. Finally Cappellari et al. (2012) exploit regional and industry differences in the timing of reforms in the legislation of fixed-term and apprenticeship contracts in Italy and find evidence of a negative effect of temporary employment on productivity.

Labour market (de)regulation may also affect firms/workers incentives and the reallocation of resources in the economy through the determination of wages. More centralized/coordinated wage-bargaining systems reduce the responsiveness of industry and firm-level wages to industry price and productivity developments (Holmlund and Zetterberg, 1991; Teulings and Hartog, 1998) with a negative effect on allocative efficiency. On the other hand, in decentralized wage- 
bargaining regimes, incentives to innovate and adopt new technologies depend crucially on workers' bargaining power. The risk of hold-up can be partly mitigated when bargaining occurs at the national level (or at the industry level but with economy-wide coordination $)^{2}$ and sets the general frame of the wage schedule (Teulings and Hartog, 1998). From an empirical point of view, Acemoglu and Pischke (1999b) find some evidence of more firm-sponsored training in more coordinated countries with potentially negative effects on productivity growth. Moreover, empirical evidence suggests countries with coordinated industrial relations systems and relatively stringent employment protection have stronger technological comparative advantage in industries characterized by cumulative technological progress than countries with decentralized wage bargaining, no coordination and low EPL (Bassanini and Ernst, 2002).

\section{Labour market facts and labour productivity trends}

\subsection{Labour market reforms}

The process of liberalisation of the Italian labour market was gradual and occurred as a sequence of incremental reforms started in the early 1980s (see Table $1)$.

\section{TABLE 1AROUND HERE}

The first wave of reforms can be dated back to the mid-80s with the introduction of the first norms aimed to regulate the use of part time (1983-84) and training/work contracts $(1984)^{3}$ and norms aimed to reduce the wage indexa-

\footnotetext{
${ }^{2}$ An industrial relations system can be said to be coordinated when: i) the wage-bargain occurs in a centralized way or co-ordination among employers and/or trade unions sets a uniform band of wages; ii) employers and trade unions co-operate as regard to decisionmaking inside the firm; and iii) business associations have an active role in solving free-riding problems across firms (Carlin and Soskice, 1990).

${ }^{3}$ Training/work contracts are temprary working arrangements (max. two years) under which an employer assumes a young workers (aged 15 to 32), combining ad hoc training
} 
tion (1986). However, it is in the early 90s that the deregulation process had a substantial acceleration partly triggered by the economic and political crisis. In 1991 a new law specified the procedures for collective firing, and it set new limits to the use of the "Cassa Integrazione Guadagni". ${ }^{4}$ The following year the automatic indexation of wages to inflation (Scala Mobile) was definitively abolished. In 1993, the so-called Giugni agreement between the government, the unions and the employers' associations introduces a comprehensive reform of wage bargaining in order to reduce inflation and to achieve higher wage flexibility. The aim of the agreement was to allow for regional differences (without excluding national coordination) in productivity levels and make wages more responsive to firms/individuals' performance and skill levels. The new collective bargaining structure was organised on two levels: national (centralised) level for the adjustments of wages to inflation dynamics and firm/regional level for the regulation of productivity-related pay schemes. In 1997, a series of reforms by Labour Minister Treu ("Pacchetto Treu") formalised the evolving flexibility arrangements in the Italian productive sectors. The reforms eased the regulation of apprenticeship schemes, part-time employment, and temporary contracts. Moreover they introduced private temporary work agencies, which even if rather limited in scope, introduced modern job matching services in an environment dominated by an inefficient public employment service. The use of fixed-term (interim) work arrangements, albeit subject to conditions such as restricting their application for low-skilled workers, boomed in subsequent years. In 1999, the rules concerning the use of interim contracts for unskilled cycles and work in the workplace.

${ }^{4} \mathrm{~A}$ peculiar feature of Italian labour market is the limited scope of the unemployment insurance. Unemployment benefits in Italy are traditionally low and available to a limited number of workers. Workers in large manufacturing however can benefit of a short-term wage replacement benefits known as "Cassa Integrazione Guadagni" (CIG).The CIG was originally introduced by a private agreement between employers' associations and unions and it is based on private and government contributions. It provides benefits proportional to wages in case of an involuntary reduction in working time or temporary layoffs. Peculiarly, workers who benefit of CIG, are nor regarded as unemployed even in case of total suspension of activity. 
jobs were eased (this condition having been largely ignored in any event). Finally in mid-2001, the new government extended the possibility and terms for use of temporary contracts, aligning Italy with EU directives. In 2003, "Biagi Law" reinforce some of the measures already introduced with Treu reform. It allowed private employment agency to compete with public ones on wider range of services, extended the use of staff-leasing contract and regulated the use of part-time work and non-standard forms of employment relationships.

In Table 2, we report the indicators for labour market institutional settings in the three periods of major reforms (as identified above) and in the pre-reform years. $^{5}$

\section{TABLE 2 AROUND HERE}

The table shows two indicators of job protection: employment protection of regular workers (i.e. workers with open ended contracts) and employment protection on temporary jobs. The index of employment protection on regular workers includes legal restrictions on dismissals and the extent of compensations in case of redundancy. Employment protection on temporary contracts concerns the rules and limitations in the use of temporary forms of employment. Regarding the institutional framework governing the wage bargaining system, the indicators reported in Table 2 consider two dimensions: the degree of centralization of the bargaining process and the extent of coordination across the social parties (unions, the employers' associations and the Government). Overall, information reported in Table 2 shows a clear trend toward a higher degree of labour market liberalization both in the use of flexible forms of employment and in the decentralization of the bargaining process. Two facts are noteworthy. First, the reforms appear to have provided flexibility through the liberalization of the use of temporary form of employment rather than the relaxation of employment protection for permanent workers. In fact, the firing rules on regular contracts have remained unchanged over the period. Conversely, the

\footnotetext{
${ }^{5}$ Labour market institutional indexes and the share of temporary contracts are from OECD $(2008,2004)$ and from ICTWSS database, Visser (2007). See note on Table 2 for detailed data descriptions.
} 
regulation of temporary contracts was eased with the consequence of increasing the share of temporary employment by almost 6 percentage points since the beginning of the reforms process (column 3). Second, the decentralization of wage bargaining, formalized with the Giugni agreement in 1993, has been accompanied by an increase in the coordination across the social parties, which has resulted in a change in the industrial relations environment and led to a period of "institutional" wage moderation.

As the labour market became more flexible, its performance improved markedly. During the 1995-2000 period, participation and employment rates rose by $2 \frac{1}{2}$ and 3 percentage points, respectively, partially reversing the trends earlier in the decade, while three-quarters of the total employment growth was registered in 1998-2000. A strong initial expansion of "atypical" work contracts, i.e. parttime and fixed-term, tended to favour women, youths and unskilled workers. The rise in female participation and employment rates (by 4 percentage points each) was particularly steep and the employment rate of youth (25-30) increased by 3 percentage points since 1997. Regarding the composition of the labour force by education attainment, data show an increase in the employment rate of low and middle skilled workers (by 2 and 3 percentage points) since the 1997 Treu Reform, while the employment rate of skilled workers has declined by almost 3 percentage points. ${ }^{6}$

\subsubsection{Labour productivity growth decomposition}

In this section we provide descriptive evidence of the decline of Italian labour productivity growth over the last thirty years, focusing on the three periods of relevant labour market reforms outlined above.

As a first step, we investigate whether the declining labour productivity trend over the whole period is the result of insufficient resource reallocation away from slow-growing industries or if instead is the consequence of the loss of

\footnotetext{
${ }^{6}$ The educational attainment concerns the highest level of education or training successfully completed. 'Low' refers to ISCED 0/1/2, 'medium' refers to ISCED 3, and 'high' refers to ISCED 5/6/7 (Source: Eurostat, 2010).
} 
dynamism of industries which used to grow fast in the past. We start decomposing aggregate labour productivity growth into the contribution of each industry taking into account three different effects: within industry, level reallocation and interaction effects.

To this end we resort to the decomposition by Foster, Haltiwanger and Krizan (2001). That is as follows:

$$
\begin{aligned}
& \frac{L P_{T}-L P_{0}}{L P_{0}}=\frac{\sum_{j} w_{j 0}\left(L P_{j T}-L P_{j 0}\right)}{L P_{0}}+\frac{\sum_{j} \Delta w_{j T}\left(L P_{j T}-L P_{0}\right)}{L P_{0}} \\
& +\frac{\sum_{j} \Delta w_{j T}\left[\left(L P_{j T}-L P_{j 0}\right)\left(L P_{T}-L P_{0}\right)\right]}{L P_{0}}
\end{aligned}
$$

where $L P_{j t}$ is the level of labour productivity in industry $j$ (aggregate if industry index is missing) at time $t(t=T, 0), w_{j t}$ is the employment share in industry $j$ at time $t$ and $\Delta w_{j T}$ is the change in the share of employment in industry $j$ between time 0 and $T$. The first summation on the right-hand side is the within effect (namely, the intra-sectoral effect), the second summation is the level reallocation effect and the third summation is the growth reallocation effect (these two last summations account for a structural-change effect). The $j$ th component of the three pieces of the equation above represents the overall contribution of industry $j$ to aggregate productivity growth. By means of this decomposition the observed reallocation effect is referred only to the shift of workers between industries.

The decomposition was carried out for four time periods (1980-1987, 19881993, 1994-2001 and 2001-2008) resorting to ISTAT - National Account data at 2digit sectoral level. Labour productivity is measured as value added per FTE employed person. The results of the decomposition are reported in Table 3. The results show that the cumulated growth of labour productivity over the period 1980-1987 was slightly above 12 percent, decreased a bit both in 1988-1993 (9.4 percent) and in 1994-2001 (7.2 percent) and declined sharply to 0.6 percent in 2001-2008 (Table 3).

TABLE 3 AROUND HERE 
The reallocative component accounts for the bulk of productivity trends in three periods out of four. The reallocative effect grasps the gain (or loss) in aggregate labour productivity stemming from a rise (or fall) in the employment share of an industry with productivity levels higher (lower) than the national average. The data indicate that there was a significant shift of employment away from less productive sectors to higher productivity industries with the exception of the last period, when the within (negative) effect dominates. Between 1980 and 1987, aggregate productivity was driven by manufacturing sector contributing for 6.9 percentage points and by agriculture for 3.9 percentage points. Services accounted only for 0.8 percentage points. In the following period, instead, the service sectors as a whole contributed for the largest share of aggregate productivity accounting for 4.6 percentage points while manufacturing contributed for 2.8 percentage points. The role of the manufacturing sector was entirely of the within type while the contribution of the services is more mixed with Trade accounting for a within effect of 2.6 percentage points and Financial services for a reallocation effect of 2.0 percentage points. This is the result of the reallocation of manufacturing employment away to other industries or to the unemployment pool at a rate of 2.5 percent over the period (Figure 1). On the contrary, employment in business services grew by 7.2 percent in 1988-93, absorbing both agriculture and manufacturing employment.

In 1994-2001, as shown in table 1, four labour market reforms entered into force giving full legal recognition to different contractual forms of part-time and temporary jobs. In the same period, labour productivity growth slowed down a bit and it was driven by a positive reallocative component in business services and a comparable positive within component in both manufacturing and trade. However, once real estate has been taken away from the business services, the reallocation effect becomes smaller and the within component turns to be the driving component of labour productivity growth. ${ }^{7}$

\footnotetext{
${ }^{7}$ As suggested by OECD in its productivity measurement guidelines, real estate has to be excluded because a significant proportion of its value added consists of "Imputed rent of owner-occupied dwellings". Since this is a pure National Accounts imputation with no buyers
} 
In 2001-2008, labour productivity growth fall down to 1.6 percent as the result of a negative within component accounting for -1.1 percentage points, because of the zeroing of manufacturing contribution ( 0.2 percentage points) and of the negative sign of the contribution from market services (-1.8 percentage points). On the other hand, the reallocation component counterbalances these effects providing a positive contribution of 2.0 percentage points. Here we might catch the effect of the extension of the use of temporary contracts that allowed more competition between private and public agencies on a larger variety of services. This might be one of the potential explanations for the still increasing employment share (3.5 per cent over the period) in the business service sectors (Figure 2).

\section{FIGURE 1 AROUND HERE}

Our industry decomposition indicates that the productivity slowdown is of a within type associated with a declining reallocation effect over the whole period. Daveri and Jona Lasinio (2005) found that over the period 1995-2003 the productivity slowdown was mainly driven by a within effect in manufacturing and by a reallocative effect in market services.

\section{Empirical strategy and data}

The aim of the empirical analysis is to assess the impact of the labour market reforms introduced in Italy in the last three decades on aggregate labour productivity level and growth. The effect on the level of productivity is mainly a compositional effect due to the fact that the availability of temporary contracts facilitate the entrance of marginal workers in the market (unskilled and low skilled workers) and the creation of jobs with a low skill content. The growth effect may be induced either by a decline in the industry productivity growth, i.e. the within component in equation (1), for the reasons we discussed

and sellers nor any associated labour input, the inclusion of "Real Estate Activities" can distort productivity measures; particularly as volume growth of owner-occupied dwellings is differs from that for other business services, (OECD, 2005). 
extensively in the previous section or by a change of the relative importance in the economy of low productive industries, i.e. the reallocative component in (1). As institutional indicators, we consider the evolution of an index for employment adjustment costs (namely the EPL index on temporary contracts elaborated by the OECD) and we take into account also two indicators of the wage bargaining regime, capturing the level at which wage bargaining occurs (being centralised, intermediate or decentralised at firm level) and the degree of coordination amongst employers representatives and unions.

The empirical analysis develops in two main steps. In the first step we evaluate the impacts of the changes in the labour market institutions on industry performance looking at both productivity level and growth effects. In the second step we focus on the growth effect and we estimate the impact of labor market reforms on the rate of growth of aggregate productivity which may occur through the industry reallocative component.

\subsection{Labour market reforms and industry productivity}

Our empirical approach follows the difference-in-differences technique first proposed by Rajan and Zingales (1998). The basic idea is to exploit the fact that labour market reforms which were common to all sectors, may have had a different impact according to industry characteristics. In particular, the effect of reforms towards a higher degree of flexibility may be stronger in sectors with a higher need of flexibility (i.e. sectors where the frequency or incidence of the adjustments of the labour force are larger because of their technological characteristics).

In line with a number of labour studies adopting the Rajan and Zingales approach (Micco and Pages, 2004; Bassanini et al., 2009 ; Cingano et al., 2010), we use job reallocation rates computed at industry level for a frictionless labour market (in our specific case for the UK) as a proxy for the "intrinsic flexibility need". The underlying assumption is that, in a deregulated environment, labour reallocation is mainly driven by country-invariant industry-specific fac- 
tors such as the technological characteristics of the production processes and the dynamics of the global demand for the industry. Following this approach we are able to differentiate the effect of reforms according to the intrinsic reallocative characteristics of each sectors and estimate more precisely their impact on productivity over the sample period.

We also interact our indicators of labour market reforms with a dummy which identifies sectors with a larger endowment of high skilled workers in order to capture differences in the impact of reforms according to the characteristics of human capital or the skill content of the jobs. Our assumption is based on the theoretical (and empirical) result that firms respond differently to a deregulation in the use of fixed-term contracts, depending on the types of jobs they create. For jobs in which a good match with the worker entails a large gain in productivity (the "high skilled" jobs), firms use fixed-term contracts to screen workers, allowing them to experiment without paying a high dismissal cost if the worker is not a good match. In this case a deregulation of fixed-term contracts would be beneficial in terms of productivity gains. For jobs in which match quality is less important (mainly in low-skilled sectors), fixed-term contracts provide flexibility against potential productivity shocks or a reduction in labour costs, implying a substitution between temporary and permanent forms of employment. ${ }^{8}$

Finally, we also distinguish between manufacturing and services in order to verify whether and to what extent labour market reforms may explain the differences in the productivity trends observed since the late $90 \mathrm{~s}$.

We then estimate the following linear regression model:

$$
Y_{j t}=Z_{t} \rho+\left(Z_{t} \times \sec _{j}\right) \psi+X_{j t} \varsigma+\lambda_{i}+\varepsilon_{i t}
$$

Where $Y_{i t}$ is labour productivity (both in level and growth rate) of sector $j$ at time $t ; Z_{t}$ are time-varying indexes of labour market institutions

\footnotetext{
${ }^{8}$ Empirical evidence of the relevance of human capital in determing the conversion of temporary contratcs into permannet ones is provided in a number of papers, among the others Casquel and Cunyat (2004) and Guell and Petrongolo (2007) for Spain, and Booth et al. (2000) for the UK.
} 
(EPL on temporary contracts, centralization index and coordination index); $\sec _{j}=\operatorname{man}, h s$, ejr are sector (time invariant) characteristics (namely a dummy for manufacturing sectors, a dummy for high skilled sectors and an index of intrinsic job reallocation respectively). The $X_{j t}$ are sectoral specific characteristics (among the other an industry-specific time trend) and $\lambda_{i}$ are industry fixed effects. Equation 2 allows better identifying the effect of $Z_{t}$ on $Y_{j t}$, exploiting variability at the sector-time level. In equation 2 , the parameter $\psi$ measures the differential effect on productivity across industries (for example the difference between sectors characterized by a high degree and a low degree of intrinsic needs of reallocation) originated by a change in the institutional variable, while $\rho$ represents the main effect of a change in the labour market regulations on productivity $^{9}$.

\subsection{Labour market institutions and the reallocation com- ponent}

In the next step, we aim to assess whether the labour market reforms affect positively the reallocative component of aggregate productivity by enhancing labour reallocation in favour of relative more productive sector or, conversely, the effect is negative by increasing job creation in sector relatively less productive. Following Brown and Earle (2004, 2006), we can express the reallocative component in equation (1) as a covariance between the change in the employment share of sector $j$ and the productivity gap of sector $j$ with respect to the average as follows:

$$
\sum_{j t} \Delta \omega_{j t}\left(L P_{j t-1}-L P_{t-1}\right)=n \operatorname{cov}\left(\Delta \omega_{j t}, L P_{j t-1}-L P_{t-1}\right)
$$

From equation 3,we then compute the average reallocative component over the sample period as the coefficient $\beta$ from the following OLS regression:

$$
\Delta \omega_{j t}=\alpha+\beta D_{j t-1}+\omega_{j t}
$$

\footnotetext{
${ }^{9} \mathrm{We}$ also estimate a set of specifications in which we substitute the industry invariant institutional endex with year dummies in order to check the robustness of the results.
} 
where $D_{j t-1}=\frac{L P_{j t-1}-L P_{t-1}}{n \operatorname{Var}\left(L P_{j t-1}-L P_{t-1}\right)}$ is the productivity gap at time $t-1$ normalized by ( $n$ times) the sample variance (normalized productivity gap) and $n$ is number of sectors.

In equation (4), $\widehat{\beta}$ can be interpreted as the average responsiveness of the industry size adjustment to its relative productivity, scaled so that the responsiveness is measured in terms of its overall contribution to aggregate productivity growth: if market works well to reallocate resources towards more productive sectors, then $\widehat{\beta}$ (the overall reallocative component) will be high, while if the reallocation process is sclerotic, $\widehat{\beta}$ will be low.

This specification allows us to express the reallocative component as a function of institutional indicators and sectoral characteristics (i.e. manufacturing production; intrinsic JR index; human capital endowment) in order to estimate the impact of changes in the institutions on the extent of productivity-enhancing reallocation.

We first estimate the following specification:

$$
\Delta \omega_{j t}=\beta D_{j t-1}+\delta\left(D_{j t-1} \times \sec _{j}\right)+\lambda_{t}+\lambda_{i}+v_{j t}
$$

where $\lambda_{t}$ and $\lambda_{i}$ are year and country dummies.

In specification (5) the first derivative with respect to $D_{j t-1}$ is an expression of the reallocative component, while the coefficient $\delta$ captures the difference in the reallocative contribution to aggregate productivity growth of sectors with different characteristics (e.g. if $\mathrm{sec}_{j}$ is 1 for manufacturing and 0 for nonmanufacturing, $\beta$ and $\beta+\delta$ represent the average reallocative contribution to aggregate productivity over the sample period of non manufacturing sectors and manufacturing sectors respectively)

Finally, we run a fully interacted model, including interactions between $D_{j t-1}, \sec _{j}$ and the (time-variant) institutional indicator $Z_{t}$ in order to capture the effect of the change in the institutional framework on the reallocative component in sectors with different characteristics. 
The empirical specification is the following:

$$
\begin{aligned}
\Delta \omega_{j t}= & \beta+\delta\left(D_{j t-1} \times \sec _{j}\right)+\left(D_{j t-1} \times Z_{t}\right) \eta+ \\
& +\left(D_{j t-1} \times Z_{t} \times \sec _{j}\right) \xi+\lambda_{t}+\lambda_{i}+v_{j t}
\end{aligned}
$$

Hence, we in principle allow for the effects of $Z_{t}$ on the reallocative component of the aggregate productivity to differ according to sectoral characteristics.

If we now take the derivative of $(6)$ with respect to $D_{j t-1}$, we obtain an expression of the reallocative component

$$
\frac{\partial \Delta \omega_{j t}}{\partial D_{j t-1}}=\beta+\delta \sec _{j}+Z_{t} \eta+\left(Z_{t} \times \sec _{j}\right) \xi
$$

which now depends both on $Z_{t}$ and industry characteristics. Our primary interest relates to the marginal effects of $Z_{t}$ on the reallocative component, hence to the partial derivative of (7) with respect to $Z_{t}$ expressed as

$$
\frac{\partial^{2} \Delta \omega_{j t}}{\partial D_{j t-1} \partial Z_{t}}=\eta+\xi \sec _{j}
$$

Let us concentrate on the impact of $Z_{t}$ on sectors with different flexibility need by assuming that $\sec _{j}$ represents the extent of intrinsic job reallocation of sector $j$. Hence $\eta<0$ and $\xi<0$ imply that the higher the flexibility need, the stronger the negative effect of the deregulation of temporary employment on the reallocative contribution to aggregate productivity.

\subsection{Data}

Productivity is measured as industry valued added per employment (full time equivalent) using data available from ISTAT National Accounts at a two digit industry classification while information on skill composition at industry level are provided by the EUKLEMS database. Our analysis is focused on the non agricultural business sectors. For this reason we exclude industries characterized by a large share of public employment such as health care service and education. We also exclude energy and utility, real estate, and renting and business activities. Our final sample includes information for 18 industries over a period of 27 years (1980-2008). 
Aggregate data on EPL and the wage bargaining centralization index are from OECD database (OECD, 2007). The EPL indicator considered in the analysis is the index of the regulation of temporary contracts and available form 1982 to 2008 . The index of the degree of centralization of the wage bargaining system is available from 1982 to $2004 .{ }^{10}$ The index for coordination of wage bargaining is taken from the ICTWSS Database compiled by Visser. ${ }^{11}$

Finally the data on gross job reallocation for the UK (the frictionless economy) are taken from Messina and Vallanti (2007) job flows database, which provides cross-country comparable job flows statistics for $13 \mathrm{EU}$ countries over the period 1990-2001. ${ }^{12}$ The UK appears a natural benchmark because the UK labour market is much less regulated in comparison to other OECD countries. Previous works have used gross job reallocation (the sum of creation and destruction rates) as a measure of reallocation intensity within a given sector in order to capture the simultaneous creation and destruction of jobs in a given period of time. However, sectors which are experiencing large changes in employment (either positive or negative) may be characterized by high gross job reallocation rates without any simultaneous creation and destruction of jobs.

\footnotetext{
${ }^{10}$ We extrapolate the OECD index of the degree of the centralization for the years 2004-2008 in order to cover all the period. Results do not change significantly.

${ }^{11}$ The ICTWSS database (Database on Institutional Characteristics of Trade Unions, Wage Setting, State Intervention and Social Pacts ) covers four key elements of modern political economies in advanced capitalist societies: trade unionism, wage setting, state intervention and social pacts. The database contains annual data for 34 countries for the period 1960-2008. Data and a description of the content of the database are publicly available on http://www.uva-aias.net/208.

${ }^{12}$ Following Davis and Haltinwanger (1990), the job reallocation rate for sector $j$ and year $t$ is costructed by summing up the absolute changes in employment nomalized for the firm size over all the firms $i$ in a given sector $j$

$$
J R_{j t}^{U K}=2 \frac{\left|n_{i j t}-n_{i j t-1}\right|}{n i_{i j t}+n_{i j t-1}}
$$

The excess job reallocation is then calculated by subtracting the net employment change at industry level and in each year. Finally we take the average of the excess job reallocation over time and obtain the index ejr $r_{j}$
} 
In order to circumvent this difficulty, we consider a closed related measure of reallocation which is the excess job reallocation. Excess job reallocation is calculated as the difference between gross reallocation and the absolute value of the net employment change and captures the reallocation over and above the amount necessary to accommodate changes in the sectoral employment over a given period of time. ${ }^{13}$

\section{$5 \quad$ Estimation results}

\subsection{Reforms and labour productivity}

We start evaluating the effects of the labour market reforms on productivity by estimating the impact of labour market deregulation on labour productivity at the industry level. As a preliminary evidence in Table 4 we report the results of a simple regression in which labour productivity (in $\log$ ) is regressed on three dummies, one for each period of major reforms as discussed in the previous sections, in order to capture any significant change in the trend of labour productivity over the period.

\section{TABLE 4 AROUND HERE}

We also interact the reform period dummies with the industry characteristics (manufacturing, high skilled and index of reallocative need in columns 2, 3 and 4 respectively) to detect any differential in labour productivity in different sectors. In all specifications we include also a trend variable in order to control for common patterns of productivity across industries over the period of analysis. The results in Table 4 show that during the first period and second period of reforms productivity increased significantly especially in manufacturing and high skilled sectors. The trend appears to reverse in correspondence with the third wave of reforms, starting from the beginning of 2000s, especially in sectors

\footnotetext{
${ }^{13}$ In our sample the cross sector correlation of gross employment reallocation and excess employment reallocation is 0.89 . Results obtained using gross job reallocation as an indicator of "sectoral intrinsic flexibility" are qualitatively and quantitatively similar and are available from the authors under request.
} 
with a lower skill content. Interestingly, the increase in labour productivity registered during the second period of reforms is less strong in high-reallocative sectors which should have been more affected by the liberalization and the trend reverses dramatically in the high reallocative sectors in last period.

In order to better assess the effect of changes in the labour market institutional settings, we estimate a second set of regressions (Table 5) substituting the period dummies with the indicators for employment protection legislation on temporary contracts $(E P L)$, wage bargaining centralization $(C E N T)$ and coordination $(C O O R) .{ }^{14}$

\section{TABLE 5 AROUND HERE}

The results unambiguously show that labour productivity is negatively affected by a relaxation of the rules governing the use of temporary contract. Such negative effect is smaller in high skilled sectors, and becomes quantitatively stronger in sectors with a higher intrinsic reallocation. The marginal effect of reducing the EPL index by 1 unit ranges from $-2.5 \%$ for the sector at 10th percentile of the distribution of the "flexibility need" (Transport, storage and communication with an ejr index equal to 0.066 ) to $-4 \%$ for the sector at the 90th percentile (Manufacture of electrical and optical equipment with an ejr index equal to 0.089). The magnitude of the effects is not negligible, and lies around $6 \%$ of the difference in labour productivity of high relative to lowreallocative sectors over the period considered. Interestingly, looking at the wage bargaining institutional framework, the process of decentralization appears to have led to a significant increase in labour productivity in sectors which employ a larger share of high skilled workers. The effect is significant and accounts for almost 3 percentage points of the differences in productivity level in favour of high-skilled sectors.

The impact of labour market institutions on productivity growth appears to

\footnotetext{
${ }^{14} \mathrm{As}$ a robustness check, we run the same regression by substituting the institutional indicators (which are time variant but common to all sectors) with time dummies in order to capture common industry shocks. The coefficients on the interaction terms in column (2) to (4) are not significantly affected once we remove the main effect.
} 
be less neat (see Table 6 and Table 7). In general, the first period of reforms registers a slight increase in the growth rate of productivity in services and low reallocative sectors, while productivity growth declines in the third period of reforms. When we consider the impact of specific institutional indicators, a larger degree of flexibility in the use of temporary forms of employment (lower EPL) has no significant effect on the rate of growth of productivity in high a low reallocative sectors.

Finally, in Tables from 8 to 11 we explore the effects of the reforms on capital deepening (level and growth). The results in Table 9 and Table 11 show that the decrease in EPL on temporary contract reduces the capital labour ratio in the high job reallocation industries, implying substitution of capital for labour in sectors where the impact of the reforms is expected to be stronger. This result is in line with the theoretical prediction that a reduction in labour costs (which is a consequence of the liberalization in the use of temporary contracts) imply a substitution of capital with more labour, and then a decline in capital deepening. Interestingly, the results shows that the positive effects on productivity of the decentralization of the bargaining process in high skilled sectors goes through an increase in the use of capital stock relative to labour input.

\subsection{Reforms and reallocation}

Here we look at the results of the second set of our estimates aimed at investigating the impact of institutional changes on the extent of productivity-enhancing reallocation. First, we test whether there are differential effects of reallocation according to some industry characteristics and then we look also at the impact of labour market reforms. Table (10) reports the results for the aggregate average reallocation effect as in the empirical specifications (4) and (5). Column (1) shows that at the aggregate level, the average reallocation contribution is positive and significant and it accounts, on average, for $0.04 \mathrm{pp}$ of yearly labour productivity growth. The reallocation effect is instead negligible in manufacturing confirming the major role of the within effect that drove the manufacturing 
contribution to labour productivity growth over the whole period (Table 3 ). The reallocation is not related with the industrial skill content since the coefficient in table (10) column (3) is not significant. In column (4) we test whether the productivity-enhancing reallocation has a different impact on aggregate productivity according to the degree of flexibility needs across sectors. The coefficient of the interaction term is negative and significant at 5 percent indicating that in those industries where the flexibility need is higher the reallocative component contribute less to the aggregate productivity growth.

Table (11) reports the complete set of estimates of equation ( (6) to test the link between institutions and the productivity-enhancing reallocation taking into account some industry characteristics. Column (1) shows that at the aggregate level, EPL does not have any impact on the reallocative contribution to aggregate productivity while the decentralization of the wage bargaining process appears to negatively affect the reallocative component. Column (3) reports the results for manufacturing as opposed to services. The EPL interaction coefficient is positive and significant indicating that a lower regulated labour market (lower EPL) reduces the reallocative contribution of services while it does not have any impact on manufacturing. Then, column (5) shows that the industry reallocative responsiveness to institutional reforms does not depend on the sectoral human capital endowment. Finally, the decline of EPL over time has a stronger impact on the reallocative contribution of those sectors with a relatively higher flexibility need. Accordingly to our estimates, the deregulation in the use of temporary contracts accounts for a decline of the reallocative contribution to aggregate growth which ranges from $0.06 \mathrm{pp}$ (low reallocative sectors) to 0.12 pp (high reallocative sectors) over the second period of reforms (1993-2000) and from $0.20 \mathrm{pp}$ to almost $0.30 \mathrm{pp}$ over the period 2001-2008. The overall impact on the aggregate productivity is not negligible and can be quantified as large as $0.30 \mathrm{pp}$ of the annual aggregate productivity growth in the period 1995-2008. 


\section{Conclusions}

The labour market deregulation has a negative effect on both the level and growth rate of productivity. Our results show that the increased flexibility in the use of temporary contract has led to a lower productivity (level and to a lesser extent growth rate) in all sectors, with a higher impact on those industries with a higher flexibility need. The marginal effect of reducing the EPL index by 1 unit, ranges from $-2.5 \%$, for the sector at 10th percentile of the distribution of "flexibility need" (Transport, storage and communication) to $-4 \%$ for the sector at the 90th percentile (Manufacture of electrical and optical equipment). Conversely, the use of temporary contracts has a significant lower effect in industries with higher skill content. This result confirms the theoretical prediction that the use of fixed-term contracts can produce different results in term of productivity losses according to the type of jobs they create. For "high skilled" jobs firms use them to screen employees with a beneficial effect on the firm-worker match (this is mainly the case for jobs created in high skilled industry). On the other hand, in sectors with a high flexibility need, fixed-term contracts provide flexibility against negative productivity shocks and a reduction in labour adjustment costs, implying a substitution between temporary and permanent forms of employment and substitution between labour and capital. Moreover the extensive use of temporary form of employment appears to have favoured the access to the labour market of the so called marginal low-productive workers (basically women, youth and unskilled workers) and/or have made profitable the creation of jobs and activities with a low skills requirement.

The negative effect of the reforms on the reallocative capacity is stronger for those industries with a higher flexibility need that are also the relatively lower productivity sectors in the period 1993-2008. At the same time these sectors experienced a larger increase in employment as a result of the deregulation process. The productivity growth differentials between the higher (above the 90th percentile) and lower (below the 10th percentile) flexibility need sectors is on average 0.5 percentage points, while higher flexibility need flexibility sectors 
experienced an average increase in employment 6 percentage points higher than sectors with lower flexibility need. Such decline in the reallocative contribution is then the result of reforms that favoured higher job creation in industries which benefited more from the reduction in the adjustment costs of the labour force. However, this has also implied an increase in the relative economic importance of sectors characterized by slower productivity dynamics with an overall negative impact on the aggregate productivity growth.

\section{References}

[1] Acemoglu D., J. Pischke (1999a), "Minimum Wages and On-the-Job Training," Working papers 99-25, Massachusetts Institute of Technology (MIT), Department of Economics

[2] Acemoglu, D., R. Shimer (1999b), "Holdups and Efficiency with Search Frictions," International Economic Review, vol. 40(4), pp. 827-49.

[3] Addessi W. (2012), "Labor Contracts and Productivity Dynamics", Paper LuissLab1298, Dipartimento di Economia e Finanza, LUISS Guido Carli.

[4] Autor, David H., William R. Kerr and Adriana D. Kugler, (2007), Do Employment Protections Reduce Productivity? Evidence from U.S. States, The Economic Journal

[5] Bartelsman, E. J. and J. Hinloopen (2005), "Unleashing animal spirits: ICT and economic growth", in L. Soete and B. ter Weel (eds.), The Economics of the Digital Economy, Edward Elgar Publishing.

[6] Bassanini A., E. Ernst, (2002), "Labour market regulation, industrial relations and technological regimes: a tale of comparative advantage," Industrial and Corporate Change, Oxford University Press, vol. 11(3), pages 391-426, June 
[7] Bassanini A., L. Nunziata and D. Venn (2009). "Job protection legislation and productivity growth in OECD countries," Economic Policy, vol. 24, pages 349-402, 04.

[8] Bassanini A. and D. Venn (2008), "The Impact of Labour Market Policies on Productivity in OECD Countries," International Productivity Monitor, Centre for the Study of Living Standards, vol. 17, pp. 3-15, Fall.

[9] Belot, M. and J.C. van Ours, 2004, Does the recent success of some OECD countries in lowering their unemployment rates lie in the clever design of their labour market reforms?, Oxford Economic Papers, vol. 56, no. 4, pp. 621-642.

[10] Bertola, G. (2004), "A Pure Theory of Job Security and Labour Income Risk," Review of Economic Studies, Blackwell Publishing, vol. 71(1), pp. 43-61, 01.

[11] Blanchard, O. J. and A. Landier (2002), "The Perverse Effects of Partial Labor Market Reform: Fixed Duration Contracts in France", Economic Journal 112, F214-244..

[12] Boeri, T. and P. Garibaldi (2007), "Two-Tier Reforms of Employment Protection Legislation: A Honeymoon Effect" Economic Journal 117, 357-385.

[13] Cappellari L., Dell'Aringa C., Leonardi M., (2012), "Temporary Employment, Job Flows and Productivity: A Tale of Two Reforms," IZA Discussion Papers 6526, Institute for the Study of Labor (IZA)

[14] Carlin W.,Soskice D., (1990), "Macroeconomics and the Wage Bargain: A Modern Approach to Employment, Inflation, and the Exchange Rate" OUP Catalogue, Oxford University Press, number 9780198772446, August.

[15] Cunyat A., E. Casquel, (2004). "The Dynamics Of Temporary Jobs In Spain” Royal Economic Society Annual Conference 2004 141, Royal Economic Society. 
[16] Cingano, F., M. Leonardi, J. Messina, and G. Pica, (2009). "The Effect of Employment Protection Legislation and Financial Market Imperfections on Investment: Evidence from a Firm-Level Panel of EU Countries", IZA Discussion Papers 4158, Institute for the Study of Labour (IZA).

[17] Cingano F, M. Leonardi, J. Messina and G. Pica (2008), Employment Protection Legislation, Productivity and Investment: Evidence from Italy, mimeograph, University of Salerno.

[18] Ciriaci D., D. Palma (2008), "The role of knowledge-based supply specialization for competitiveness: a spatial econometric approach", Papers in Regional Science, Special issue on Spatial Econometrics, vol. 87, n. 3, 2008.

[19] Codogno L. (2009), "Two Italian Puzzles: Are Productivity Growth and Competitiveness Really so Depressed?", Working Papers wp2009-2, Department of the Treasury, Ministry of the Economy and of Finance.

[20] Daveri F., C. Jona Lasinio. (2005), "Italy's Decline: Getting the Facts Right", Giornale degli Economisti e Annali di Economia, vol. 64(4), pp. 365-410, December.

[21] Dew-Becker I.,R.J. Gordon, (2008), "The Role of Labor Market Changes in the Slowdown of European Productivity Growth" NBER Working Papers 13840, National Bureau of Economic Research, Inc.

[22] Faini R., A. Sapir (2005), "Un Modello obsoleto? Crescita e specializzazione dell'economia italiana, in Oltre il declino, ed. Tito Boeri, Riccardo Faini, Andrea Ichino, Giuseppe Pisauro, e Carlo Scarpa, Il Mulino, Bologna 2005.

[23] Foster L., J. C. Haltiwanger, C. J. Krizan, (2001), "Aggregate Productivity Growth. Lessons from Microeconomic Evidence" NBER Chapters, in: New Developments in Productivity Analysis, pages 303-372 National Bureau of Economic Research, Inc. 
[24] Gambacorta R. (2004) "Il dibattito sulla legge di Verdoorn: alcuni risultati empirici usando l'analisi della cointegrazione", Rivista di Politica Economica, vol. V-VI, pp. 251-277.

[25] Guell, M. and B. Petrongolo (2007), "How Binding are Legal Limits?: Transitions from Temporary to Permanent Work in Spain" Labour Economics $14,153-183 .$.

[26] Hopenhayn, H. and R. Rogerson (1993), "Job Turnover and Policy Evaluation: A General Equilibrium Analysis" Journal of Political Economy 103, 915-938.

[27] Holmlund, B., J. Zetterberg (1991), "Insider effects in wage determination: Evidence from five countries" European Economic Review, Elsevier, vol. 35(5), pages 1009-1034, July.

[28] Huselid, M., (1995). "The impact of human resource management practices on turnover, productivity and corporate financial performance", Academy of Management Journal, 38, pp. 635-670.

[29] Kent C. and J. Simon, (2007), Productivity Growth: The Effect of Market Regulations," RBA Research Discussion Papers rdp2007-04, Reserve Bank of Australia.

[30] Ichino, A. and R. T. Riphahn, (2005), "The Effect of Employment Protection on Worker Effort: A Comparison of Absenteeism During and After Probation" Journal of the European Economic Association, 3(1), 120-143).

[31] Lucidi F. (2008), "Labour market flexibility and productivity growth: new evidence from firm-level data", XXIII National Conference of Labour Economics, Brescia, 11-12 September 2008.

[32] Lucidi F., A. Kleinknecht (2009), "Little innovation, many jobs: An econometric analysis of the Italian labour Productivity", Cambridge Journal of Economics 
[33] McCombie J.S.L., Pugno M. e Soro B. (2002), eds. Productivity Growth and Economic Performance, London, Palgrave Macmillan.

[34] McCombie J.S.L., A. P. Thirlwall (1994), Economic Growth and the Balance of Payment Constraint, St. Martin's Press, Basingstoke.

[35] Messina J and G. Vallanti (2007), "Job Flow Dynamics and Firing Restrictions: Evidence from Europe," Economic Journal, R, vol. 117(521), pages 279-301, 06.

[36] Micco A.and C.Pages,(2004), "Employment protection and gross job flows: a differences-in-differences approach" mimeograph, World Bank.

[37] Michie, J. and Sheehan, M. (2003). "Labour market deregulation, 'flexibility' and innovation", Cambridge Journal of Economics, 27, pp. 123-143.

[38] Naastepad, C.W.M. and Storm, S. (2005). "The innovating firm in a societal context: productivity, labour relations and real wages", in Verburg R., Ortt J.R. \& Dicke W. (Eds), Management of Technology: An Introduction, London: Routledge.

[39] Bell, S. Nickell, (1996), "Would Cutting Payroll Taxes on the Unskilled Have a Significant Effect on Unemployment?" CEP Discussion Papers dp0276, Centre for Economic Performance, LSE

[40] OECD (2006), Employment Outlook (Paris: OECD).

[41] OECD (2007), "More Jobs But Less Productive? The Impact of Labour Market Policies on Productivity: OECD Employment Outlook, (Paris: OECD).

[42] Poschke, M. (2007), "Employment protection, firrm selection, and growth" IZA Discussion Paper 3164.

[43] Rajan, R. and Zingales, L. (1998), Financial Dependence and Growth American Economic Review 88, 559-586. 
[44] Scarpetta, S. and T. Tressel (2004), Boosting Productivity via Innovation and Adoption of New Technologies: Any Role for Labour Market Institutions?, World Bank Working Paper No. 3273

[45] Visser, J.(2009), "Data Base on Istitutional Characterisctics of Trade Unions, Wage Setting, Sate Intervention and Social Pacts, 1960-2008. Amsterdam Institute for Advanced Labor Studies.

[46] Wasmer, Etienne, 2006. "The Economics of Prozac (Do Employees Really Gain from Strong Employment Protection?)", CEPR Discussion Papers 5991. 
TABLE 1. Labour Market Reforms in Italy (breaking points)

\begin{tabular}{|l|l|}
\hline & Reforms description \\
\hline $1984-1987$ & $\begin{array}{l}\text { Introduction of part-time and training contracts (1983-84); reduction in } \\
\text { the wage indexation (1986). }\end{array}$ \\
\hline $1991-1993$ & $\begin{array}{l}\text { New procedures for collecting firing and limits to the use of Cassa } \\
\text { Integrazione e Guadagni; abolishment of indexation (1992); Giugni } \\
\text { agreement (1993) which introduces two-tiers wage bargaining (centralized } \\
\text { and at firm level) }\end{array}$ \\
\hline $1994-1995$ & $\begin{array}{l}\text { Extension of the training contracts () to a wider range of situations and } \\
\text { the collaboration contracts are introduced (no firing and hiring costs) }\end{array}$ \\
\hline $1997-1998$ & $\begin{array}{l}\text { Pacchetto Treu (end of 1997): new atypical contracts such as job-sharing; } \\
\text { use of temporary worker agency; new fiscal treatment of part-time work. }\end{array}$ \\
\hline 2001 & $\begin{array}{l}\text { Decree Law no. 368: Fixed term contracts are extended to regular } \\
\text { employees . }\end{array}$ \\
\hline 2003 & $\begin{array}{l}\text { Legge Biagi which provides a common framework to atypical contracts } \\
\text { and extends further the use of TWA }\end{array}$ \\
\hline
\end{tabular}


TABLE 2. Labour Market Institutional Indicators

\begin{tabular}{|c|c|c|c|c|}
\hline & $\begin{array}{l}\text { EPL regular } \\
\text { contracts }^{(a)}\end{array}$ & $\begin{array}{c}\text { EPL } \\
\text { temporary } \\
\text { contracts }^{(b)}\end{array}$ & $\begin{array}{l}\text { Centralization } \\
\text { index }^{(c)}\end{array}$ & $\begin{array}{l}\text { Coordination } \\
\text { index }^{(\mathrm{d})}\end{array}$ \\
\hline 1980-1986 & 1.77 & 5.38 & 3 & 2.86 \\
\hline 1987-1992 & 1.77 & 5.38 & 2 & 2.33 \\
\hline $1993-2000$ & 1.77 & 4.60 & 2 & 4.00 \\
\hline 2001-2008 & 1.77 & 1.99 & 2 & 4.00 \\
\hline
\end{tabular}

Note: (a) EPL regular contracts: measures the costs of dismissals of redundant workers and includes legal restrictions on dismissals and the extent of compensations in case of redundancy.; (OECD, 2004). (b) EPL temporary contracts: measures the restrictions on the use of temporary employment by firms, with respect to the type of work for which these contracts are allowed and their duration (scale: 1-6); OECD (2004). (c) Centralization index: the dominant level(s) at which wage bargaining takes place (scale: 1-3); OECD (2004). (d) Coordination index: coordination of wage bargaining (scale1-5). 4=mixed industry and economy-wide bargaining (key unions and employers associations set pattern for the entire economy); $2=$ mixed industry- and firm level bargaining, with weak enforceability of industry agreements; ICTWSS database (Visser, 2007). 


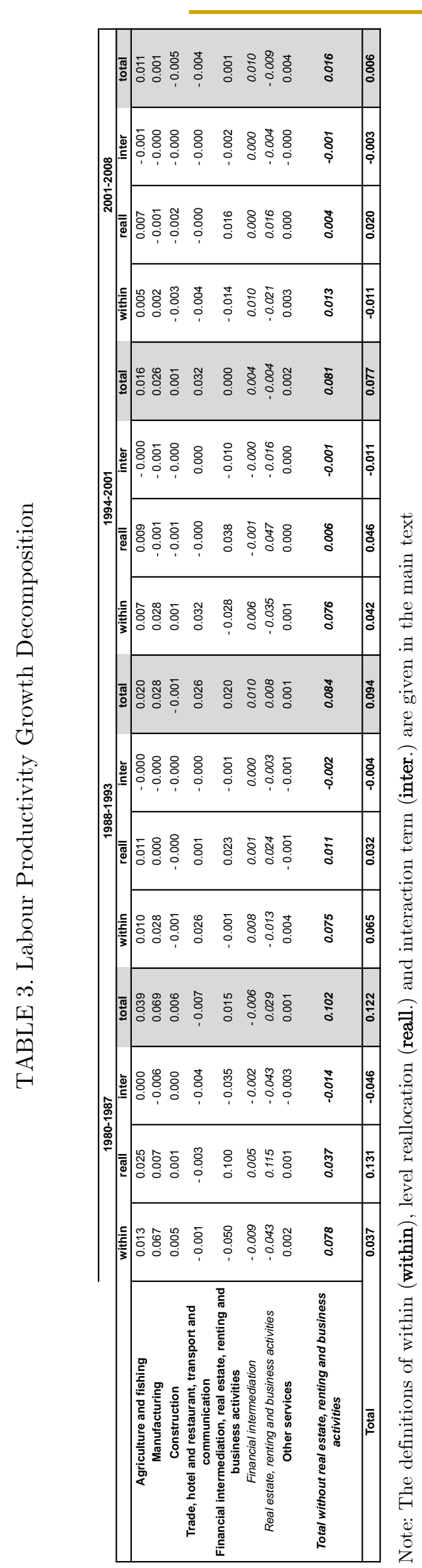


TABLE 4. Labour Productivity: Period Dummies

\begin{tabular}{lcccc}
\hline Dep. var.=LP & $(1)$ & $\begin{array}{c}\text { man } \\
(2)\end{array}$ & $\begin{array}{c}\text { hs } \\
(3)\end{array}$ & $\begin{array}{c}\text { ejr } \\
(4)\end{array}$ \\
& & & & \\
\hline per1 & 0.071 & -0.056 & 0.039 & 0.060 \\
& $(4.01)^{* * *}$ & $(1.53)$ & $(1.62)$ & $(0.64)$ \\
per2 & 0.056 & 0.066 & 0.052 & 0.322 \\
& $(3.18)^{* * *}$ & $(3.21)^{* * *}$ & $(2.74)^{* * *}$ & $(5.94)^{* * *}$ \\
per3 & -0.069 & -0.055 & -0.083 & 0.013 \\
& $(3.26)^{* * *}$ & $(1.76)^{*}$ & $(3.37)^{* * *}$ & $(0.17)$ \\
per1 x sect & & 0.066 & 0.061 & 0.139 \\
& & $(4.14)^{* * *}$ & $(1.91)^{*}$ & $(0.11)$ \\
per2 $x$ sect & & -0.012 & 0.007 & -3.518 \\
& & $(0.74)$ & $(0.45)$ & $(5.13)^{* * *}$ \\
per3 $x$ sect & & -0.018 & 0.027 & -1.082 \\
& & $(0.64)$ & $(1.32)$ & $(1.10)$ \\
& & & & \\
\hline Observations & 518 & 518 & 518 & 518 \\
R-squared & 0.88 & 0.89 & 0.89 & 0.89 \\
Industry & yes & yes & yes & yes \\
trend & yes & yes & yes & yes \\
\hline
\end{tabular}

Note: Robust standard errors in parentheses. All the regressions include an industry trend and industry fixed effects. LP is the (log of) value added per worker (FTE). The period dummies are defined as follows: per $1=1$ if year $>1986,0$ otherwise; per $2=1$ if year $>1992,0$ otherwise; per $3=1$ if year $>2000$, 0 otherwise. Sect is man, hs and ejr in column (2), (3) and (4) respectively; man is a dummy with value 1 for manufacturing industry, 0 otherwise; $h s$ is a dummy with value 1 for high skilled sectors (share of workers with an underground degree or more above the median), 0 otherwise; ejr is the average industry excess job reallocation calculated for the UK sectors over the period 1990-2000. The median of ejr is 0.074

* significant at $10 \%$;* significant at $5 \%$; *** significant at $1 \%$. 
TABLE 5. Labour Productivity: Institutional Indicators

\begin{tabular}{lcccc}
\hline Dep. var.= LP & $(1)$ & $\begin{array}{c}\text { man } \\
(2)\end{array}$ & $\begin{array}{c}\text { hs } \\
(3)\end{array}$ & $\begin{array}{c}\text { ejr } \\
(4)\end{array}$ \\
\hline EPL & 0.032 & 0.025 & 0.038 & -0.029 \\
& $(3.53)^{* * *}$ & $(2.18)^{* *}$ & $(4.10)^{* * *}$ & $(1.11)$ \\
CENT & -0.053 & 0.048 & -0.024 & -0.176 \\
& $(1.42)$ & $(0.87)$ & $(0.61)$ & $(1.37)$ \\
COORD & 0.009 & 0.007 & 0.009 & 0.067 \\
& $(0.99)$ & $(0.43)$ & $(0.84)$ & $(1.84)^{*}$ \\
EPL X sect & & 0.009 & -0.015 & 0.815 \\
& & $(0.92)$ & $(2.14)^{* *}$ & $(2.54)^{* *}$ \\
CENT X sect & & -0.071 & -0.073 & 1.629 \\
& & $(1.54)$ & $(1.82)^{*}$ & $(0.98)$ \\
COORD X sect & & 0.003 & 0.001 & -0.772 \\
& & $(0.21)$ & $(0.11)$ & $(1.58)$ \\
& & & & \\
\hline Observations & 466 & 466 & 466 & 466 \\
R-squared & 0.88 & 0.90 & 0.89 & 0.89 \\
Industry & yes & yes & yes & yes \\
trend & yes & yes & yes & yes \\
\hline
\end{tabular}

Note: Robust standard errors in parentheses. All the regressions include an aggregate trend and industry fixed effects. LP is the (log of) value added per worker (FTE). EPL is the employment protection legislation on temporary contracts; CENT is an indicator for the centralization of the wage bargaining process; COORD is an indicator for the coordination of the wage bargaining process. Sect is man, hs and ejr in column (2), (3) and (4) respectively; man is a dummy with value 1 for manufacturing industry, 0 otherwise; $h s$ is a dummy with value 1 for high skilled sectors (share of workers with an underground degree or more above the median), 0 otherwise; ejr is the average industry excess job reallocation calculated for the UK sectors over the period 1990-2000. The median of ejr is 0.074

* significant at $10 \% ;{ }^{* *}$ significant at $5 \%$; *** significant at $1 \%$. 
TABLE 6. Labour Productivity Growth: Period Dummies

\begin{tabular}{lcccc}
\hline Dep. var.=dLP & $(1)$ & $\begin{array}{c}\text { man } \\
(2)\end{array}$ & $\begin{array}{c}\text { hs } \\
(3)\end{array}$ & $\begin{array}{c}\text { ejr } \\
(4)\end{array}$ \\
& & & & \\
\hline per1 & 0.003 & 0.037 & 0.009 & 0.056 \\
& $(0.53)$ & $(3.65)^{* * *}$ & $(1.17)$ & $(1.98)^{* *}$ \\
per2 & 0.003 & 0.013 & 0.000 & 0.014 \\
& $(0.37)$ & $(1.40)$ & $(0.01)$ & $(0.55)$ \\
per3 & -0.020 & -0.018 & -0.021 & -0.062 \\
& $(2.82)^{* * *}$ & $(1.86)^{*}$ & $(2.48)^{* *}$ & $(2.38)^{* *}$ \\
per1 x sect & & -0.043 & -0.012 & -0.693 \\
& & $(3.83)^{* * *}$ & $(1.07)$ & $(1.87)^{*}$ \\
per2 $x$ sect & & -0.013 & 0.005 & -0.147 \\
& & $(1.56)$ & $(0.65)$ & $(0.45)$ \\
per3 $x$ sect & & -0.003 & 0.001 & 0.551 \\
& & $(0.28)$ & $(0.14)$ & $(1.69)^{*}$ \\
& & & & \\
\hline Observations & 500 & 500 & 500 & 500 \\
R-squared & 0.16 & 0.22 & 0.16 & 0.17 \\
Industry & yes & yes & yes & yes \\
trend & yes & yes & yes & yes \\
\hline
\end{tabular}

Note: Robust standard errors in parentheses. All the regressions include an industry trend and industry fixed effects. dLP is the labour productivity growth rate. The period dummies are defined as follows: per $1=1$ if year $>1986,0$ otherwise; per $2=1$ if year $>1992,0$ otherwise; per $3=1$ if year $>2000$, 0 otherwise. Sect is man, hs and ejr in column (2), (3) and (4) respectively; man is a dummy with value 1 for manufacturing industry, 0 otherwise; $h s$ is a dummy with value 1 for high skilled sectors (share of workers with an underground degree or more above the median), 0 otherwise; ejr is the average industry excess job reallocation calculated for the UK sectors over the period 1990-2000. The median of ejr is 0.074

$*$ significant at $10 \%$; ${ }^{* *}$ significant at $5 \%$; ${ }^{* *}$ significant at $1 \%$. 
TABLE 7. Labour Productivity Growth: Institutional Indicators

\begin{tabular}{lcccc}
\hline Dep. var.= dLP & $(1)$ & $\begin{array}{c}\text { man } \\
(2)\end{array}$ & $\begin{array}{c}\text { hs } \\
(3)\end{array}$ & $\begin{array}{c}\text { ejr } \\
(4)\end{array}$ \\
\hline EPL & 0.005 & 0.002 & 0.005 & 0.016 \\
& $(1.61)$ & $(0.49)$ & $(1.42)$ & $(1.94)^{*}$ \\
CENT & -0.011 & -0.045 & -0.016 & -0.088 \\
& $(1.10)$ & $(3.30)^{* * *}$ & $(1.46)$ & $(3.16)^{* * *}$ \\
COORD & 0.007 & 0.003 & 0.005 & 0.014 \\
& $(2.35)^{* *}$ & $(0.65)$ & $(1.77)^{*}$ & $(1.35)$ \\
EPL $x$ sect & & 0.004 & 0.001 & -0.145 \\
& & $(1.44)$ & $(0.33)$ & $(1.44)$ \\
CENT X sect & & 0.043 & 0.014 & 1.027 \\
& & $(3.57)^{* * *}$ & $(1.17)$ & $(2.88)^{* * *}$ \\
COORD X sect & & 0.005 & 0.003 & -0.102 \\
& & $(1.32)$ & $(0.75)$ & $(0.73)$ \\
& & & & \\
\hline Observations & 466 & 466 & 466 & 466 \\
R-squared & 0.18 & 0.23 & 0.18 & 0.19 \\
Industry & yes & yes & yes & yes \\
trend & yes & yes & yes & yes \\
\hline
\end{tabular}

Note: Robust standard errors in parentheses. All the regressions include an aggregate trend and industry fixed effects. dLP is labour productivity growth rate. EPL is the employment protection legislation on temporary contracts; CENT is an indicator for the centralization of the wage bargaining process; COORD is an indicator for the coordination of the wage bargaining process. Sect is man, hs and ejr in column (2), (3) and (4) respectively; man is a dummy with value 1 for manufacturing industry, 0 otherwise; $h s$ is a dummy with value 1 for high skilled sectors (share of workers with an underground degree or more above the median), 0 otherwise; ejr is the average industry excess job reallocation calculated for the UK sectors over the period 1990-2000. The median of ejr is 0.074

* significant at $10 \% ;{ }^{* *}$ significant at $5 \% ;{ }^{* * *}$ significant at $1 \%$. 
TABLE 8. Capital to Labour Ratio: Period Dummies

\begin{tabular}{lcccc}
\hline Dep. var.= KL & $(1)$ & $\begin{array}{c}\text { man } \\
(2)\end{array}$ & $\begin{array}{c}\text { hs } \\
(3)\end{array}$ & $\begin{array}{c}\text { ejr } \\
(4)\end{array}$ \\
\hline per1 & 0.156 & 0.011 & -0.014 & 0.088 \\
& $(9.39)^{* * *}$ & $(0.35)$ & $(0.66)$ & $(1.28)$ \\
per2 & 0.184 & 0.044 & -0.004 & 0.269 \\
& $(16.06)^{* * *}$ & $(1.86)^{*}$ & $(0.19)$ & $(5.07)^{* * *}$ \\
per3 & 0.142 & -0.052 & -0.017 & 0.101 \\
& $(10.27)^{* * *}$ & $(1.77)^{*}$ & $(0.76)$ & $(1.50)$ \\
per1 x sect & & -0.003 & 0.058 & -1.075 \\
& & $(0.10)$ & $(1.80)^{*}$ & $(1.21)$ \\
per2 $x$ sect & & -0.025 & 0.072 & -3.265 \\
& & $(1.23)$ & $(3.52)^{* * *}$ & $(4.86)^{* * *}$ \\
per3 $x$ sect & & 0.029 & -0.031 & -1.744 \\
& & $(1.00)$ & $(1.13)$ & $(1.98)^{* *}$ \\
& & & & \\
\hline Observations & 505 & 505 & 505 & 505 \\
R-squared & 0.88 & 0.90 & 0.89 & 0.89 \\
Industry & yes & yes & yes & yes \\
trend & yes & yes & yes & yes \\
\hline
\end{tabular}

Note: Robust standard errors in parentheses. All the regressions include an industry trend and industry fixed effects. KL is the (log of) capital to labour ratio. The period dummies are defined as follows: per $1=1$ if year $>1986,0$ otherwise; per $2=1$ if year $>1992,0$ otherwise; per $3=1$ if year $>2000,0$ otherwise. Sect is man, hs and ejr in column (2), (3) and (4) respectively; man is a dummy with value 1 for manufacturing industry, 0 otherwise; $h s$ is a dummy with value 1 for high skilled sectors (share of workers with an underground degree or more above the median), 0 otherwise; ejr is the average industry excess job reallocation calculated for the UK sectors over the period 1990-2000. The median of ejr is 0.074

* significant at $10 \%$;* significant at $5 \%$; *** significant at $1 \%$. 
TABLE 9. Capital to Labour Ratio: Institutional Indicators

\begin{tabular}{lcccc}
\hline Dep. var.= KL & & man & hs & ejr \\
& $(1)$ & $(2)$ & $(3)$ & $(4)$ \\
\hline EPL & 0.006 & 0.009 & 0.004 & -0.070 \\
& $(0.59)$ & $(0.75)$ & $(0.46)$ & $(2.92)^{* * *}$ \\
CENT & -0.024 & -0.049 & 0.010 & -0.194 \\
& $(0.74)$ & $(1.16)$ & $(0.33)$ & $(2.48)^{* *}$ \\
COORD & 0.014 & 0.019 & 0.005 & 0.075 \\
& $(1.61)$ & $(1.52)$ & $(0.54)$ & $(2.47)^{* *}$ \\
EPL $x$ sect & & -0.004 & 0.003 & 0.997 \\
& & $(0.43)$ & $(0.32)$ & $(3.36)^{* * *}$ \\
CENT $x$ sect & & 0.032 & -0.088 & 1.251 \\
& & $(0.82)$ & $(2.30)^{* *}$ & $(2.15)^{* *}$ \\
COORD X sect & & -0.007 & 0.024 & -0.810 \\
& & $(0.54)$ & $(1.86)^{*}$ & $(2.04)^{* *}$ \\
& & & & \\
\hline Observations & 468 & 468 & 468 & 468 \\
R-squared & 0.88 & 0.90 & 0.89 & 0.89 \\
Industry & yes & yes & yes & yes \\
trend & yes & yes & yes & yes \\
\hline
\end{tabular}

Note: Robust standard errors in parentheses. All the regressions include an aggregate trend and industry fixed effects. KL is the ( $\log$ of) capital to labour ratio. EPL is the employment protection legislation on temporary contracts; CENT is an indicator for the centralization of the wage bargaining process; COORD is an indicator for the coordination of the wage bargaining process. Sect is man, hs and ejr in column (2), (3) and (4) respectively; man is a dummy with value 1 for manufacturing industry, 0 otherwise; $h s$ is a dummy with value 1 for high skilled sectors (share of workers with an underground degree or more above the median), 0 otherwise; ejr is the average industry excess job reallocation calculated for the UK sectors over the period 1990-2000. The median of ejr is 0.074

${ }^{*}$ significant at $10 \% ;{ }^{* *}$ significant at $5 \% ;{ }^{* * *}$ significant at $1 \%$. 
TABLE 10. Capital to Labour Ratio Growth: Period Dummies

\begin{tabular}{|c|c|c|c|c|}
\hline Dep. var. $=\mathrm{dKL}$ & (1) & $\begin{array}{c}\operatorname{man} \\
(2)\end{array}$ & $\begin{array}{l}\text { hs } \\
(3)\end{array}$ & $\begin{array}{l}\text { ejr } \\
(4)\end{array}$ \\
\hline per1 & $\begin{array}{l}-0.009 \\
(2.16)^{* *}\end{array}$ & $\begin{array}{l}0.033 \\
(4.70) * * *\end{array}$ & $\begin{array}{l}-0.001 \\
(0.11)\end{array}$ & $\begin{array}{l}0.060 \\
(2.56)^{* *}\end{array}$ \\
\hline per2 & $\begin{array}{l}-0.004 \\
(1.32)\end{array}$ & $\begin{array}{l}-0.000 \\
(0.06)\end{array}$ & $\begin{array}{l}0.013 \\
(2.20)^{* *}\end{array}$ & $\begin{array}{l}-0.012 \\
(0.67)\end{array}$ \\
\hline per3 & $\begin{array}{l}-0.007 \\
(2.07)^{* *}\end{array}$ & $\begin{array}{l}0.010 \\
(1.52)\end{array}$ & $\begin{array}{l}0.013 \\
(1.99)^{* *}\end{array}$ & $\begin{array}{l}0.018 \\
(1.05)\end{array}$ \\
\hline per1 $x$ sect & & $\begin{array}{l}-0.039 \\
(5.43)^{* * *}\end{array}$ & $\begin{array}{l}0.009 \\
(1.03)\end{array}$ & $\begin{array}{l}-0.763 \\
(2.53)^{* *}\end{array}$ \\
\hline per $2 \times$ sect & & $\begin{array}{l}0.012 \\
(1.80)^{*}\end{array}$ & $\begin{array}{c}-0.011 \\
(1.49)\end{array}$ & $\begin{array}{l}0.271 \\
(1.18)\end{array}$ \\
\hline per3 $x$ sect & & $\begin{array}{l}-0.004 \\
(0.58)\end{array}$ & $\begin{array}{l}-0.013 \\
(1.98)^{* *}\end{array}$ & $\begin{array}{l}-0.149 \\
(0.67)\end{array}$ \\
\hline Observations & 487 & 487 & 487 & 487 \\
\hline R-squared & 0.18 & 0.23 & 0.21 & 0.20 \\
\hline Industry & yes & yes & yes & yes \\
\hline trend & yes & yes & yes & yes \\
\hline
\end{tabular}

Note: Robust standard errors in parentheses. All the regressions include an industry trend and industry fixed effects. dKL is the growth rate of the capital to labour ratio The period dummies are defined as follows: per $1=1$ if year $>1986,0$ otherwise; per $2=1$ if year $>1992,0$ otherwise; per $3=1$ if year $>2000,0$ otherwise. Sect is man, hs and ejr in column (2), (3) and (4) respectively; man is a dummy with value 1 for manufacturing industry, 0 otherwise; $h s$ is a dummy with value 1 for high skilled sectors (share of workers with an underground degree or more above the median), 0 otherwise; ejr is the average industry excess job reallocation calculated for the UK sectors over the period 1990-2000. The median of ejr is 0.074

* significant at $10 \% ;{ }^{* *}$ significant at $5 \%$; *** significant at $1 \%$. 
TABLE 11. Capital to Labour Ratio Growth: Institutional Indicators

\begin{tabular}{lcccc}
\hline Dep. var.= KL & $(1)$ & $\begin{array}{c}\text { man } \\
(2)\end{array}$ & $\begin{array}{c}\text { hs } \\
(3)\end{array}$ & $\begin{array}{c}\text { ejr } \\
(4)\end{array}$ \\
\hline EPL & 0.001 & 0.001 & -0.001 & -0.002 \\
& $(0.45)$ & $(0.36)$ & $(0.59)$ & $(0.29)$ \\
CENT & 0.002 & -0.024 & 0.005 & -0.040 \\
& $(0.40)$ & $(3.87)^{* * *}$ & $(0.80)$ & $(1.70)^{*}$ \\
COORD & 0.006 & -0.001 & 0.006 & -0.004 \\
& $(3.31)^{* * *}$ & $(0.30)$ & $(2.78)^{* * *}$ & $(0.48)$ \\
EPL X sect & & 0.000 & 0.007 & 0.036 \\
CENT x sect & & $(0.15)$ & $(3.07)^{* * *}$ & $(0.52)$ \\
& & 0.034 & -0.007 & 0.564 \\
COORD $x$ sect & & $(5.90)^{* * *}$ & $(0.89)$ & $(1.87)^{*}$ \\
& & 0.009 & 0.001 & 0.135 \\
& & $(3.22)^{* * *}$ & $(0.25)$ & $(1.19)$ \\
Observations & 468 & 468 & & \\
R-squared & 0.21 & 0.26 & 0.23 & 0.21 \\
Industry & yes & yes & yes & yes \\
trend & yes & yes & yes & yes \\
\hline
\end{tabular}

Note: Robust standard errors in parentheses. All the regressions include an aggregate trend and industry fixed effects. dKL is the growth rate of the capital to labour ratio. EPL is the employment protection legislation on temporary contracts; CENT is an indicator for the centralization of the wage bargaining process; COORD is an indicator for the coordination of the wage bargaining process. Sect is man, hs and ejr in column (2), (3) and (4) respectively; man is a dummy with value 1 for manufacturing industry, 0 otherwise; $h s$ is a dummy with value 1 for high skilled sectors (share of workers with an underground degree or more above the median), 0 otherwise; ejr is the average industry excess job reallocation calculated for the UK sectors over the period 1990-2000. The median of ejr is 0.074

* significant at $10 \% ;{ }^{* *}$ significant at $5 \% ;{ }^{* * *}$ significant at $1 \%$. 
TABLE 12. Reallocative Component and Industry Characteristics

\begin{tabular}{llccc}
\hline Dep. var. $=\mathrm{dw}$ & man & hs & ejr \\
& $(1)$ & $(2)$ & $(3)$ & $(4)$
\end{tabular}

\begin{tabular}{lcccc}
\hline$D$ & 0.0024 & 0.0023 & 0.0024 & 0.0034 \\
$D$ x sect & $(3.07)^{* * *}$ & $(3.96)^{* * *}$ & $(2.89)^{* * *}$ & $(2.14)^{* *}$ \\
& & -0.0024 & 0.0006 & -0.437 \\
& & $(3.75)^{* * *}$ & $(0.25)$ & $(2.03)^{* *}$
\end{tabular}

\begin{tabular}{lcccc}
\hline Observations & 502 & 502 & 502 & 502 \\
R-squared & 0.18 & 0.36 & 0.19 & 0.23 \\
Industry & yes & yes & yes & yes \\
\hline
\end{tabular}

Note: Robust standard errors in parentheses. All the regressions include industry fixed effects. $\mathrm{dw}$ is change in labour share. $\mathrm{D}$ is the lagged deviation of the industry's productivity from the aggregate productivity divided by (n times) the variance. Sect is man, hs and ejr in column (2), (3) and (4) respectively; man is a dummy with value 1 for manufacturing industry, 0 otherwise; hs is a dummy with value 1 for high skilled sectors (share of workers with an underground degree or more above the median), 0 otherwise; ejr is the average industry excess job reallocation calculated for the UK sectors over the period 1990-2000. The median of ejr is 0.074 .

* significant at $10 \%$; ${ }^{* *}$ significant at $5 \%$; $* *$ significant at $1 \%$. 
TABLE 13. Reallocative Component: Period Dummies

\begin{tabular}{lcccc}
\hline Dep. var.= dw & $(1)$ & $\begin{array}{c}\text { man } \\
(2)\end{array}$ & $\begin{array}{c}\text { hs } \\
(3)\end{array}$ & $\begin{array}{c}\text { ejr } \\
(4)\end{array}$ \\
& & & & \\
\hline$D$ & 0.0030 & 0.0366 & 0.0030 & 0.0336 \\
& $(3.41)^{* * *}$ & $(5.70)^{* * *}$ & $(3.23)^{* * *}$ & $(2.13)^{* *}$ \\
D x sect & & -0.0318 & 0.0072 & -0.4218 \\
& & $(5.44)^{* * *}$ & $(3.98)^{* * *}$ & $(1.97)^{* *}$ \\
$D$ x per1 & -0.0006 & 0.0121 & -0.0006 & -0.0017 \\
& $(2.23)^{* *}$ & $(1.57)$ & $(2.09)^{* *}$ & $(0.36)$ \\
$D$ x per2 & 0.0000 & -0.0048 & 0.0000 & 0.0091 \\
& $(0.57)$ & $(1.04)$ & $(0.72)$ & $(2.46)^{* *}$ \\
$D$ x per3 & -0.0000 & -0.0132 & 0.0000 & -0.0042 \\
& $(0.01)$ & $(4.06)^{* * *}$ & $(0.02)$ & $(1.45)$ \\
$D$ x per1 x sect & & -0.0122 & -0.0063 & 0.0162 \\
& & $(1.59)$ & $(2.83)^{* * *}$ & $(0.26)$ \\
$D$ x per2 x sect & & 0.0048 & -0.0022 & -0.1212 \\
& & $(1.05)$ & $(1.33)$ & $(2.46)^{* *}$ \\
$D$ x per3 x sect & & 0.0132 & -0.0000 & 0.0613 \\
& & $(4.04)^{* * *}$ & $(0.15)$ & $(1.48)$ \\
\hline & & & & \\
Observations & 502 & 502 & 502 & 502 \\
R-squared & 0.18 & 0.36 & 0.19 & 0.23 \\
Industry & yes & yes & yes & yes \\
\hline
\end{tabular}

Note: Robust standard errors in parentheses. All the regressions include industry fixed effects. $\mathrm{dw}$ is change in labour share. D is the lagged deviation of the industry's productivity from the aggregate productivity divided by (n times) the variance. The period dummies are defined as follows: per $1=1$ if year $>1986,0$ otherwise; per $2=1$ if year $>1992,0$ otherwise; per $3=1$ if year $>2000,0$ otherwise. Sect is man, hs and ejr in column (2), (3) and (4) respectively; man is a dummy with value 1 for manufacturing industry, 0 otherwise; $h s$ is a dummy with value 1 for high skilled sectors (share of workers with an underground degree or more above the median), 0 otherwise; ejr is the average industry excess job reallocation calculated for the UK sectors over the period 1990-2000. The median of ejr is 0.074

* significant at $10 \%$; ${ }^{* *}$ significant at $5 \%$; $* * *$ significant at $1 \%$. 
TABLE 14. Reallocative Component: Institutional Indicators

\begin{tabular}{|c|c|c|c|c|}
\hline Dep. var. $=\mathrm{dw}$ & (1) & $\begin{array}{c}\operatorname{man} \\
(2)\end{array}$ & $\begin{array}{l}\text { hs } \\
(3)\end{array}$ & $\begin{array}{l}\text { ejr } \\
(4)\end{array}$ \\
\hline $\mathrm{D}$ & $\begin{array}{c}0.0023 \\
(2.47)^{* *}\end{array}$ & $\begin{array}{l}0.0582 \\
(1.96)^{*}\end{array}$ & $\begin{array}{c}0.0020 \\
(2.56)^{* *}\end{array}$ & $\begin{array}{c}0.0371 \\
(1.70)^{*}\end{array}$ \\
\hline $\mathrm{D} \times \mathrm{sect}$ & & $\begin{array}{l}-0.0576 \\
(1.93)^{*}\end{array}$ & $\begin{array}{c}-0.0168 \\
(2.60)^{* * *}\end{array}$ & $\begin{array}{c}-0.4974 \\
(1.63)\end{array}$ \\
\hline $\mathrm{D} \times \mathrm{EPL}$ & $\begin{array}{c}-0.0000 \\
(0.42)\end{array}$ & $\begin{array}{c}0.0042 \\
(3.85)^{* * *}\end{array}$ & $\begin{array}{c}-0.0000 \\
(0.64)\end{array}$ & $\begin{array}{c}-0.0006 \\
(0.71)\end{array}$ \\
\hline D x CENT & $\begin{array}{c}0.0006 \\
(2.26)^{* *}\end{array}$ & $\begin{array}{c}-0.0132 \\
(1.28)\end{array}$ & $\begin{array}{c}0.0006 \\
(2.18)^{* *}\end{array}$ & $\begin{array}{c}0.0000 \\
(0.03)\end{array}$ \\
\hline $\mathrm{D} \times \mathrm{COORD}$ & $\begin{array}{c}0.0000 \\
(1.62)\end{array}$ & $\begin{array}{c}-0.0024 \\
(0.92)\end{array}$ & $\begin{array}{c}0.0000 \\
(1.63)\end{array}$ & $\begin{array}{l}0.0017 \\
(1.19)\end{array}$ \\
\hline$D \times E P L \times$ sect & & $\begin{array}{c}-0.0043 \\
(3.84)^{* * *}\end{array}$ & $\begin{array}{c}0.0006 \\
(1.47)\end{array}$ & $\begin{array}{c}0.0210 \\
(1.75)^{*}\end{array}$ \\
\hline D x CENT $x$ sect & & $\begin{array}{c}0.0132 \\
(1.29)\end{array}$ & $\begin{array}{c}0.0066 \\
(3.84)^{* * *}\end{array}$ & $\begin{array}{c}0.0048 \\
(0.07)\end{array}$ \\
\hline D x COORD x sect & & $\begin{array}{c}0.0025 \\
(0.94)\end{array}$ & $\begin{array}{c}-0.0000 \\
(0.36) \\
\end{array}$ & $\begin{array}{c}-0.0264 \\
(1.12) \\
\end{array}$ \\
\hline Observations & 468 & 468 & 468 & 468 \\
\hline R-squared & 0.18 & 0.37 & 0.19 & 0.22 \\
\hline Industry & yes & yes & yes & yes \\
\hline \multicolumn{5}{|c|}{$\begin{array}{l}\text { Note: Robust standard errors in parentheses. All the regressions include industry fixed effects. } \\
\text { dw is change in labour share. D is the lagged deviation of the industry's productivity from the } \\
\text { aggregate productivity divided by (n times) the variance. EPL is the employment protection } \\
\text { legislation on temporary contracts; CENT is an indicator for the centralization of the wage } \\
\text { bargaining process; COORD is an indicator for the coordination of the wage bargaining process. } \\
\text { Sect is man, hs and ejr in column }(2),(3) \text { and (4) respectively; man is a dummy with value } 1 \\
\text { for manufacturing industry, } 0 \text { otherwise; hs is a dummy with value } 1 \text { for high skilled sectors } \\
\text { (share of workers with an underground degree or more above the median), } 0 \text { otherwise; ejr is the } \\
\text { average industry excess job reallocation calculated for the UK sectors over the period } 1990-2000 \text {. } \\
\text { The median of ejr is } 0.074 \\
{ }^{*} \text { significant at } 10 \% ;{ }^{* *} \text { significant at } 5 \% \text {; }{ }^{* * *} \text { significant at } 1 \% \text {. }\end{array}$} \\
\hline
\end{tabular}


Figure1. Industry Labour Share: Period 1 vs. Period 2

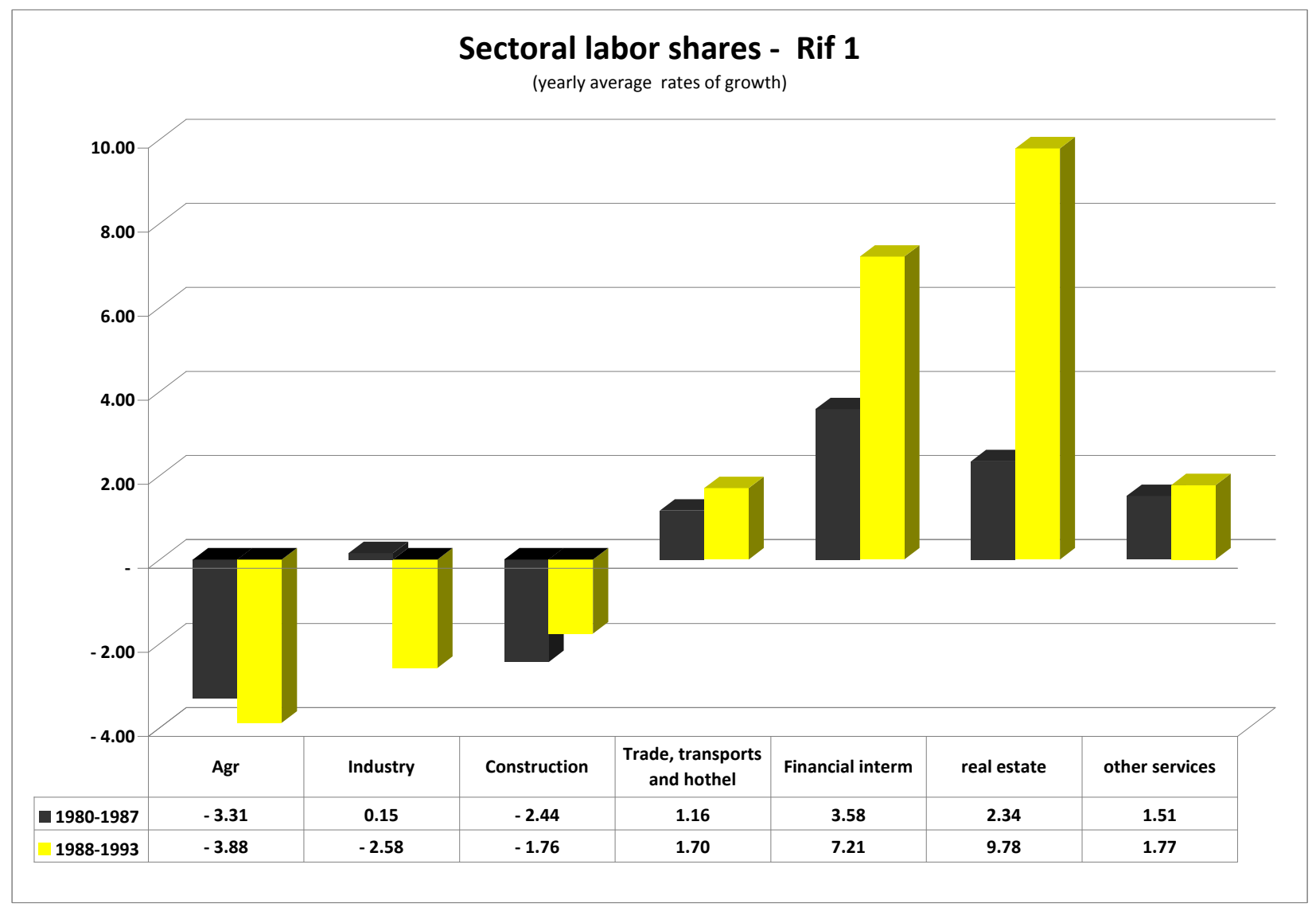


Figure2. Industry Labour Share: Period 3 vs. Period 4

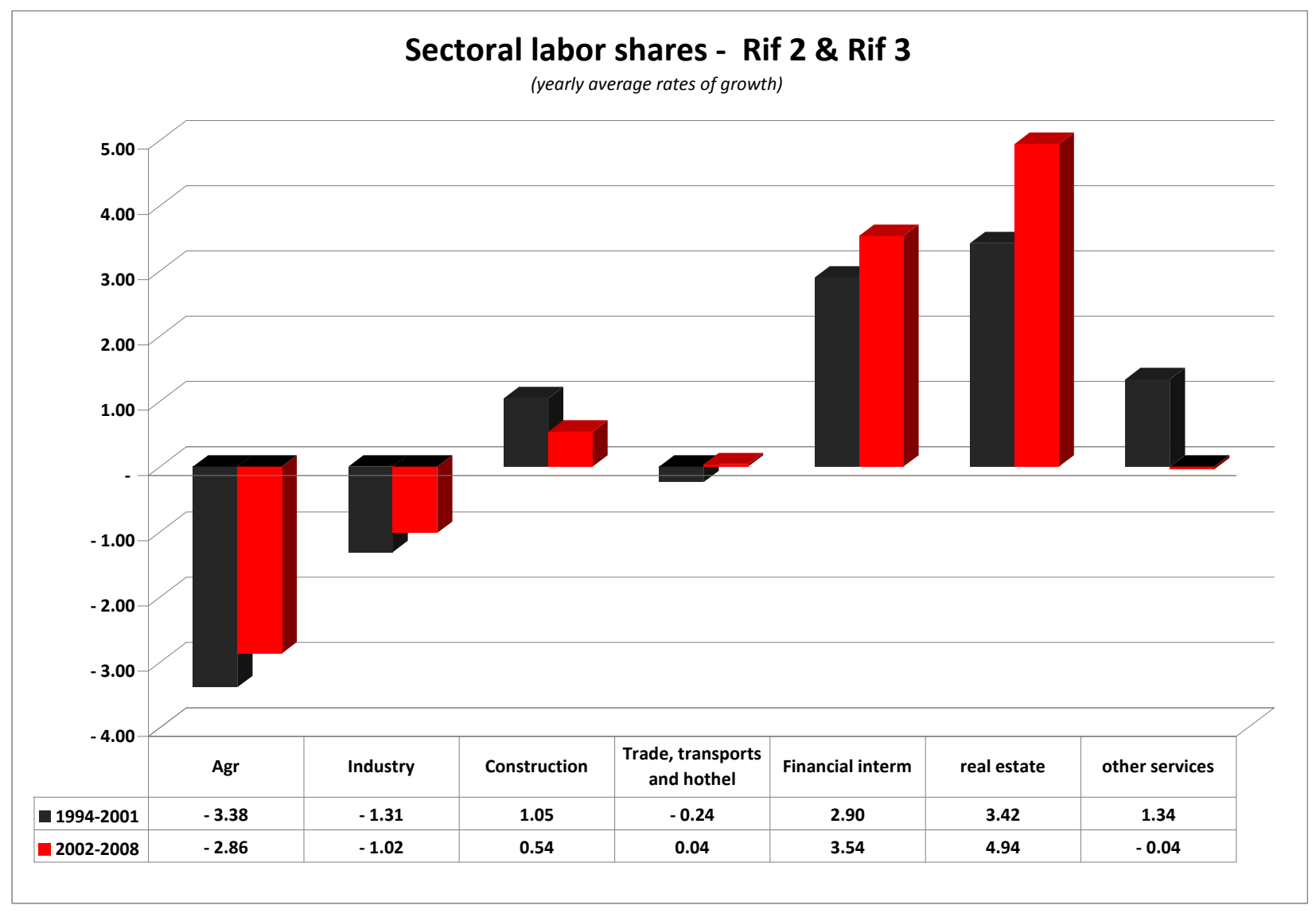





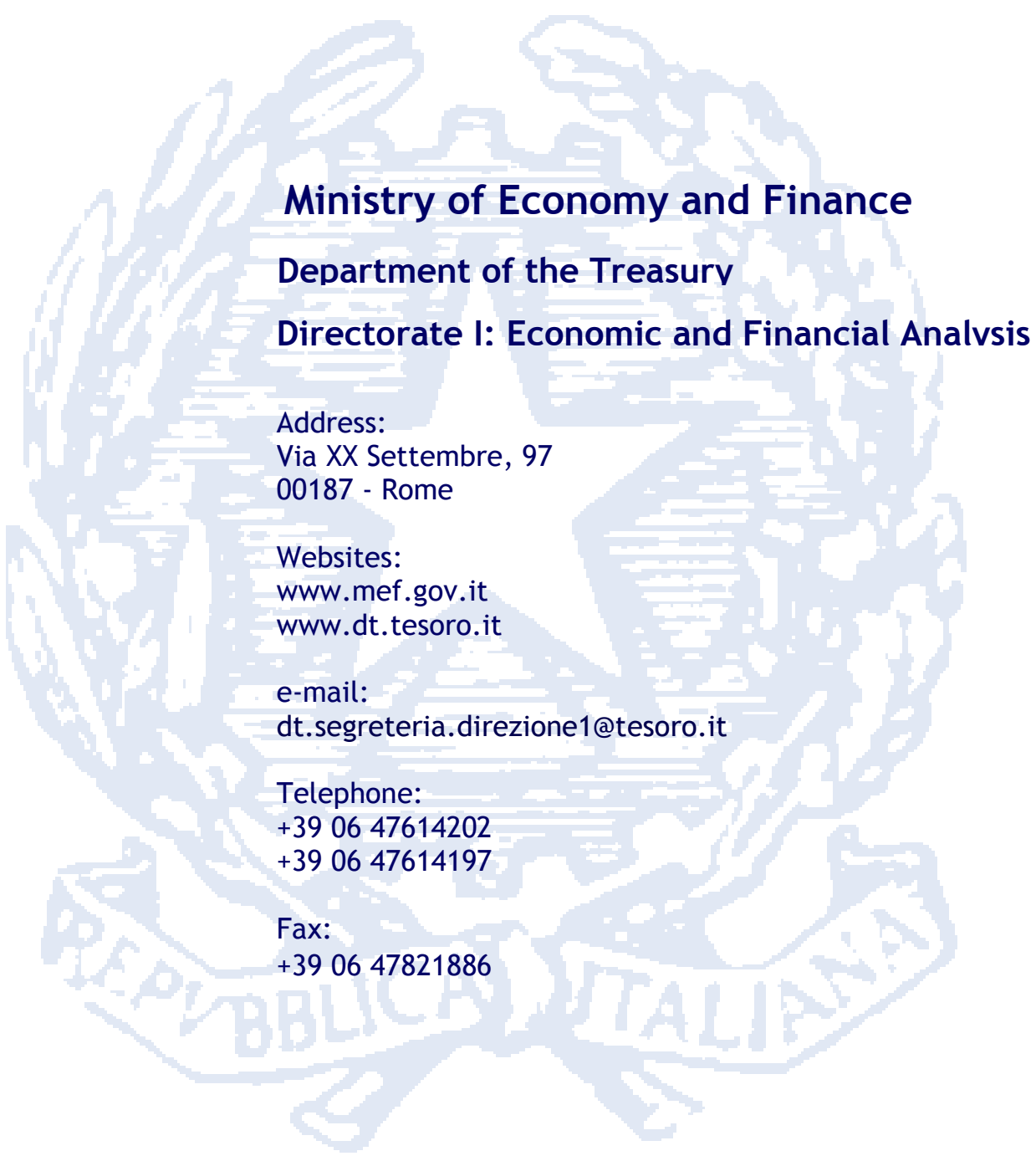

